\title{
EVENTOS PLUVIOMÉTRICOS CONCENTRADOS NO ESPAÇO URBANO:
}

\author{
Bacia do Córrego das Tabocas em Uberlândia - MG
}

\author{
Arlei Teodoro de Queiroz \\ Professor de Geografia - IFMS \\ arleiteodoro@yahoo.com.br \\ Washington Luiz Assunção \\ Professor do Instituto de Geografia - UFU \\ wlassuncao@gmail.com
}

\begin{abstract}
Resumo
O intenso processo de urbanização pelo qual passou o Brasil nas últimas décadas, culminou num crescimento desordenado da maioria das cidades brasileiras. Tal processo resultou em vários problemas associados ao planejamento inadequado da ocupação do espaço urbano, intensificando a ocorrência de enchentes provocadas por eventos pluviométricos intensos devido, principalmente, ao alto grau de impermeabilização dos solos no espaço urbano, à drenagem urbana deficitária e à ocupação antrópica de áreas de preservação permanente. Desse modo, este estudo tem o objetivo de analisar a ocorrência de dois eventos pluviométricos concentrados na Bacia do Córrego das Tabocas, em Uberlândia - MG, ocorridos nos dias 12 e 26 de novembro de 2007, relacionando a urbanização com a ocorrência e a gênese de precipitações concentradas e seus impactos na infraestrutura urbana. Os dados obtidos demonstraram que o grau de impermeabilização do solo na área da bacia é alto e a drenagem é ineficiente. Além disso, notou-se nos eventos analisados a atuação de sistemas produtores de instabilidade na ocorrência de eventos pluviométricos concentrados no período.
\end{abstract}

Palavras-chave: Urbanização, precipitação, enchentes, drenagem e Bacia do Córrego das Tabocas.

\section{EVENTS RAINFALL CONCENTRATED IN URBAN SPACE:}

\section{Watershed Stream of Tabocas in Uberlândia - MG}

\begin{abstract}
The intense process of urbanization by which passed Brazil in last decades, culminated in a disorderly growth of the majority of Brazilian cities. Such process resulted in several problems related to inadequate planning of the occupation of urban space, intensifying the occurrence of floods caused by intense rainfall events, mainly due to the high degree of soil sealing in urban space, the deficit urban drainage and human occupation of areas permanent preservation. That way, this work aims at analyze the occurrence of two rainfall events concentrated in the Watershed Stream of Tabocas in Uberlândia-MG, that occurred on days 12 and 26 November 2007 by relating the urbanization with the occurrence and the genesis of

Recebido em 02/09/2016 / Aprovado para publicação em 03/07/2018.
\end{abstract}

OBSERVATORIUM: Revista Eletrônica de Geografia, v. 9, n. 3, p. 235-261. set./dez. 2018. 
concentrated rainfall and its impacts on urban infrastructure. The data obtained demonstrated that the degree of soil sealing in area of the watershed is high and the drainage is inefficient. Besides that, it was noted in the events analyzed the acting of producers of instability systems in the occurrence of concentrated rainfall events in the period.

Keywords: Urbanization, rainfall, floods, drainage and Watershed Stream of Tabocas.

\section{Introdução}

O intenso processo de urbanização pelo qual o Brasil passou nas últimas décadas, culminou num crescimento desordenado da maioria das cidades brasileiras.

Esse processo de urbanização associado ao planejamento inadequado do espaço urbano é um agravante para a intensificação da ocorrência de enchentes provocadas por eventos pluviométricos intensos. Isso ocorre devido, principalmente, ao alto grau de impermeabilização dos solos no espaço urbano, que dificulta a infiltração das águas pluviais, à drenagem urbana, que muitas vezes se apresenta deficitária, e à ocupação antrópica de áreas de preservação permanente, intensificando, assim, o escoamento superficial pluvial, principalmente, em direção aos fundos de vale, concentrando um grande volume de águas pluviais nesses locais, provocando estragos na infraestrutura instalada.

$\mathrm{Na}$ cidade de Uberlândia nota-se que existem locais que apresentam diversos problemas relacionados com a drenagem urbana, inundações e enchentes. Dentre estes locais, pode-se destacar os córregos São Pedro (Avenida Rondon Pacheco), Cajubá (Avenida Getúlio Vargas) e Tabocas (Avenida Professora Minervina Cândida de Oliveira), que foram submetidos à retificação e canalização fechada.

Além dos problemas relacionados à drenagem urbana, outro agravante são algumas alterações climáticas que podem ocorrer no espaço urbano, definidas por Monteiro (2003), como o Sistema Clima Urbano. Sendo que o Sistema Clima Urbano pode ser dividido em três campos de estudo:

- Campo Termo-higrométrico, no qual são enfatizados os estudos de ilhas de calor e de frescor urbanas, do conforto/desconforto térmico, de inversões térmicas, etc.;

- Campo Físico-químico ou Dispersão, voltado à análise da dinâmica do ar na sua interação com a cidade, destacando a poluição do ar, as chuvas ácidas, a relação entre a estrutura urbana e os ventos, etc.; e

- Campo Hidrometeórico, relacionado ao estudo das precipitações urbanas e seus impactos, tais como os processos de inundações nas cidades. (MENDONÇA, 2003, p. 178)

Ainda sobre o clima urbano, de acordo com Ayoade (2002), há um aumento na precipitação em áreas urbanas devido aos seguintes fatores:

OBSERVATORIUM: Revista Eletrônica de Geografia, v. 9, n. 3, p. 235-261. set./dez. 2018. 
O EVENTOS PLUVIOMÉTRICOS CONCENTRADOS NO ESPAÇO URBANO:

Bacia do Córrego das Tabocas em Uberlândia - MG

Arlei Teodoro de Queiroz; Washington Luiz Assunção

[...] aos poluentes que asseguram uma abundância de núcleos de condensação.

[...] o acréscimo de vapor d'água devido aos vários processos de combustão, a convecção térmica sobre a ilha de calor urbano e a turbulência mecânica criada pelo efeito fricção das estruturas da cidade sobre os fluxos de ar. (AYOADE, 2002, p.309)

Além das alterações citadas sobre o clima local das cidades, outras ações antrópicas possuem forte influência sobre o meio ambiente no espaço urbano, como: a impermeabilização dos solos; a canalização dos cursos d'água; a acomodação de resíduos sólidos em locais indevidos e/ou obstruindo as galerias pluviais; o desmatamento e a ocupação imprópria das áreas de encosta; a deficiência no planejamento e execução de obras de infraestrutura urbana, associados ao aumento da precipitação já justificada, provocam o agravamento das enchentes e inundações. Sendo que, de acordo com Conti (1998), as chuvas podem ser consideradas intensas a partir de $30 \mathrm{~mm} / \mathrm{h}$ e críticas quando ultrapassam $50 \mathrm{~mm} / \mathrm{h}$.

A partir dessas definições, o presente trabalho tem como objetivo principal realizar uma análise no campo hidrometeórico na Bacia do Córrego das Tabocas, localizada na área urbana de Uberlândia, dando ênfase a dois eventos pluviométricos concentrados ocorridos nos dias 12 e 26 de novembro de 2007, relacionando a urbanização com a ocorrência e a gênese destas precipitações concentradas e seus impactos na infraestrutura urbana.

\section{Caracterização da área de estudo}

A Bacia do Córrego das Tabocas está localizada na área urbana de Uberlândia, conforme pode ser visualizada no Mapa 1, sendo delimitada pelas coordenadas UTM: Leste: $775.000 \mathrm{~m}$ a $800.000 \mathrm{~m}$ e Norte: $7.895 .000 \mathrm{~m}$ a 7.916.000m, abrangendo os seguintes bairros: Umuarama, Marta Helena, Brasil, Nossa Senhora Aparecida, Bom Jesus, Presidente Roosevelt, Martins, Osvaldo Rezende e Jardim Brasília. Deve-se ressaltar, ainda, que a área de drenagem da bacia abrange apenas parte desses bairros, com exceção do bairro Bom Jesus, que está todo dentro da bacia. 
O EVENTOS PLUVIOMÉTRICOS CONCENTRADOS NO ESPAÇO URBANO:

Bacia do Córrego das Tabocas em Uberlândia - MG

Arlei Teodoro de Queiroz; Washington Luiz Assunção

Mapa 1 - Localização da Bacia do Córrego das Tabocas no Perímetro Urbano de Uberlândia.

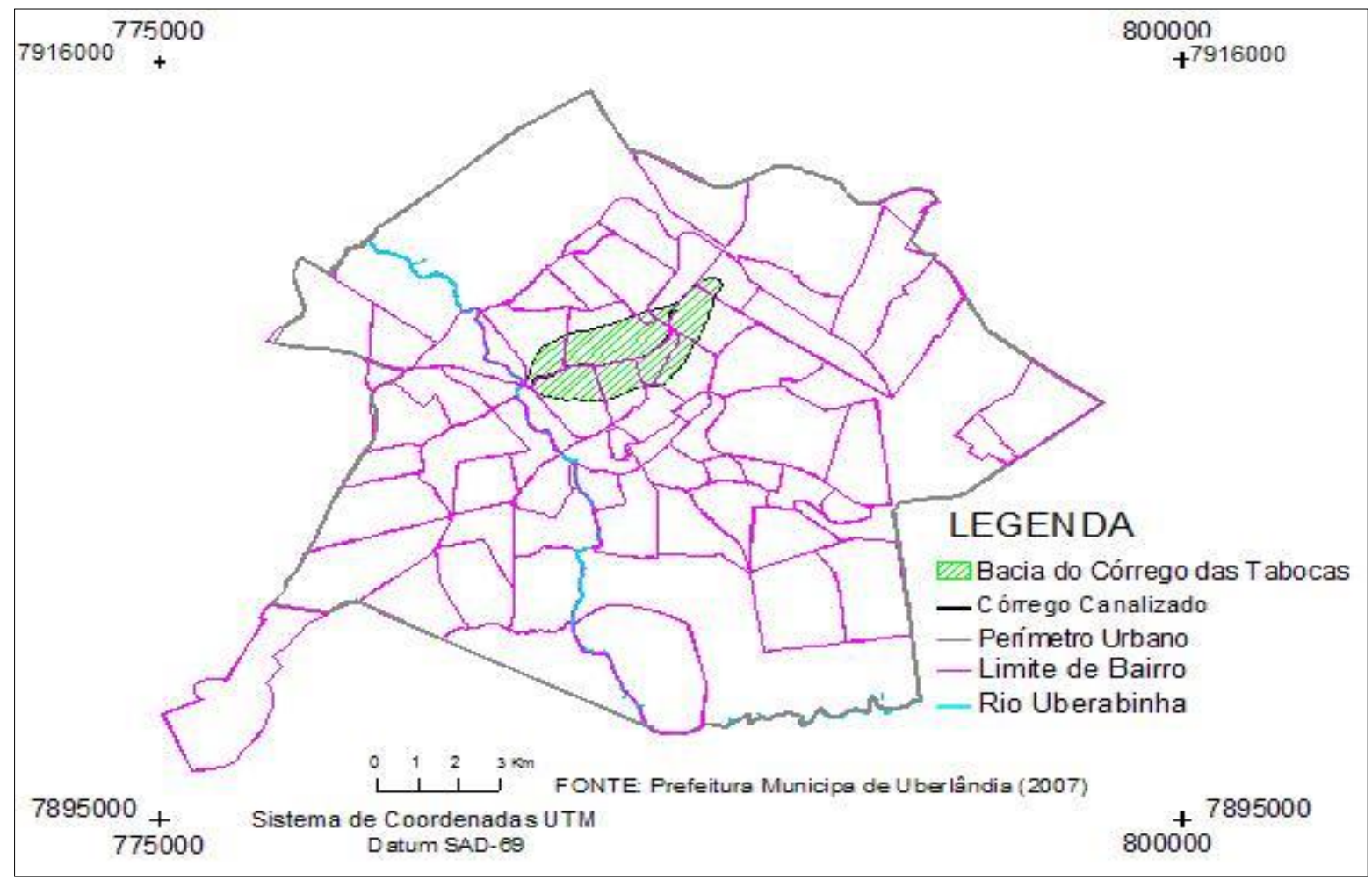

Fonte: Prefeitura Municipal de Uberlândia, 2007.

Segundo uma compilação de dados realizada pela Prefeitura de Uberlândia, utilizando informações do censo demográfico de 2010, os bairros que fazem parte da bacia possuíam uma população de 105.156 habitantes, lembrando que essa população é a soma da população de cada bairro e, como já citado anteriormente, a área da bacia abrange apenas parte da área desses bairros.

A Bacia do Córrego das Tabocas possui uma área total de $8,1338 \mathrm{Km}^{2}$. O Córrego das Tabocas é totalmente urbano, sendo afluente da margem direita do Rio Uberabinha, que por sua vez está inserido na Bacia do Rio Araguari, que faz parte da Bacia do Rio Paranaíba, que está inserida na Região Hidrográfica do Paraná.

Sobre o uso do solo na Bacia (Mapa 2), nota-se que, em 2007, a maior área permeável estava localizada na direção norte e noroeste. Isso pode ser explicado pelo fato de a direção sul ser o centro de Uberlândia, ou seja, o local onde a urbanização aconteceu há mais tempo e, por isso, tem uma área permeável relativamente menor. $\mathrm{Na}$ Bacia pode-se observar que apenas $24,13 \%$ da área é permeável, enquanto que o restante $(75,87 \%)$ possui solo impermeável, tanto pelo asfalto das ruas, como pelo concreto nos quintais e jardins das residências, passeios das ruas, telhado das casas e do comércio.

Mapa 2 - Uso do solo urbano na Bacia do Córrego das Tabocas - Uberlândia-MG.

OBSERVATORIUM: Revista Eletrônica de Geografia, v. 9, n. 3, p. 235-261. set./dez. 2018. 
O EVENTOS PLUVIOMÉTRICOS CONCENTRADOS NO ESPAÇO URBANO:

Bacia do Córrego das Tabocas em Uberlândia - MG

Arlei Teodoro de Queiroz; Washington Luiz Assunção

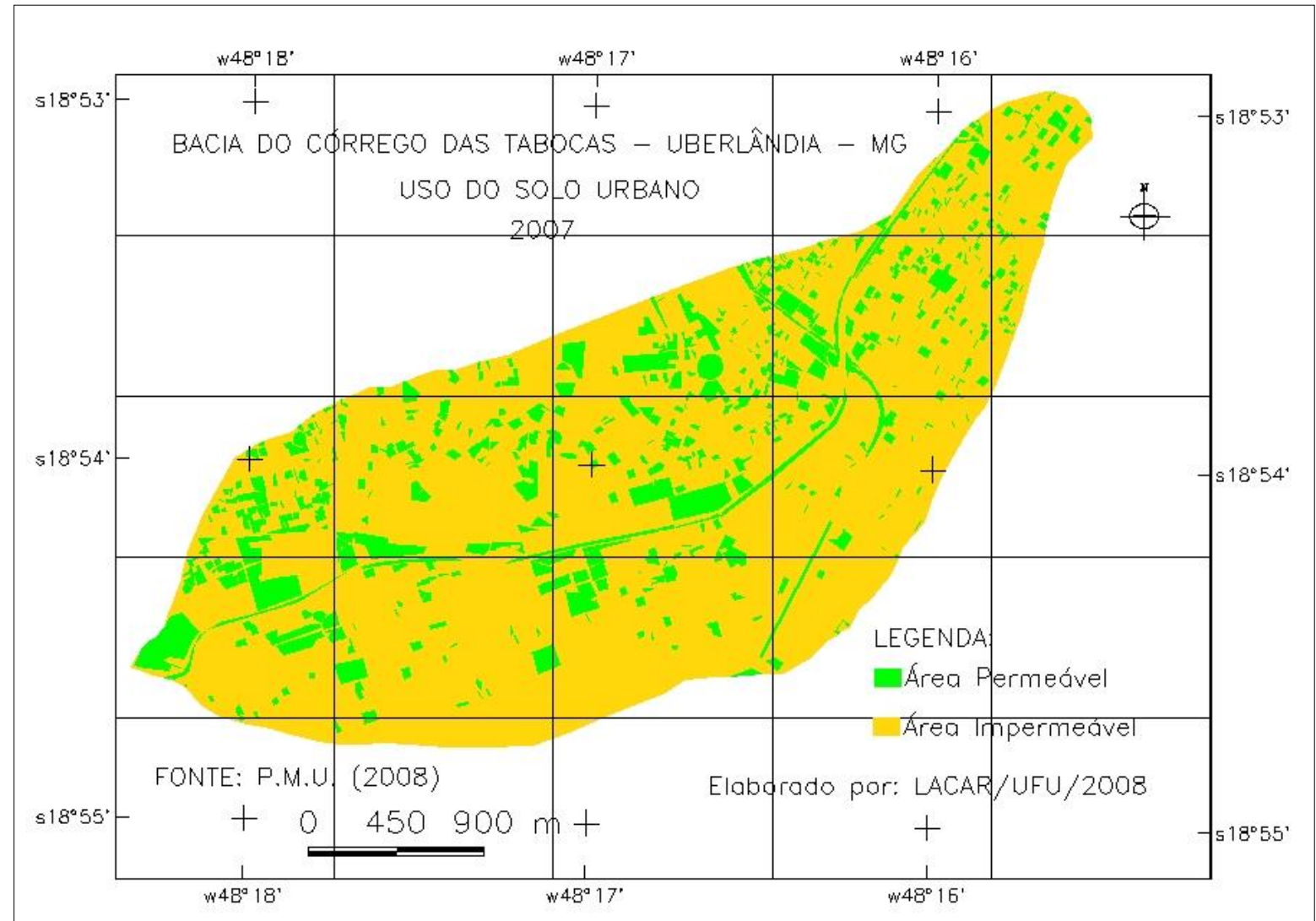

Fonte: Prefeitura Municipal de Uberlândia, 2008.

Esse alto grau de impermeabilização do solo, além de não absorver parte das águas pluviais, contribui para o aumento na velocidade da água, concentrando as águas pluviais no fundo do vale e provocando enchentes nesse local.

Além da impermeabilização do solo, outro fator que intensifica o potencial das enchentes é o acumulo de resíduos sólidos na cidade, tais como os da construção civil, que muitas vezes provocam o entupimento das entradas da galeria pluvial (bueiros, bocas-de-lobo, etc.). Tal fato ocorre de forma mais intensa, sobretudo, durante o início do período chuvoso, pois é comum a ocorrência de descarte e/ou armazenamento de forma inapropriada destes resíduos durante o período seco, provocando o entupimento das entradas da galeria pluvial quando ocorre as primeiras precipitações (período de setembro a novembro).

Já no final do período chuvoso, o solo saturado é outro fator que agrava o problema das enchentes, pois nas áreas permeáveis da bacia o solo já saturado dificulta a infiltração das águas pluviais, intensificando, assim, o escoamento superficial pluvial.

Ao observar o Mapa 3, que apresenta a altitude na Bacia, nota-se que as maiores altitudes estão à montante da Bacia, chegando a aproximadamente 950 metros, e as menores estão à jusante, com altitudes de aproximadamente 750 metros. Este desnível de quase 200 
O EVENTOS PLUVIOMÉTRICOS CONCENTRADOS NO ESPAÇO URBANO:

Bacia do Córrego das Tabocas em Uberlândia - MG

Arlei Teodoro de Queiroz; Washington Luiz Assunção

metros, em uma área relativamente pequena, contribui para o ganho de energia no escoamento superficial pluvial, contribuindo para que a água arraste objetos que encontre pela frente.

Mapa 3 - Altimetria da Bacia do Córrego das Tabocas - Uberlândia-MG.

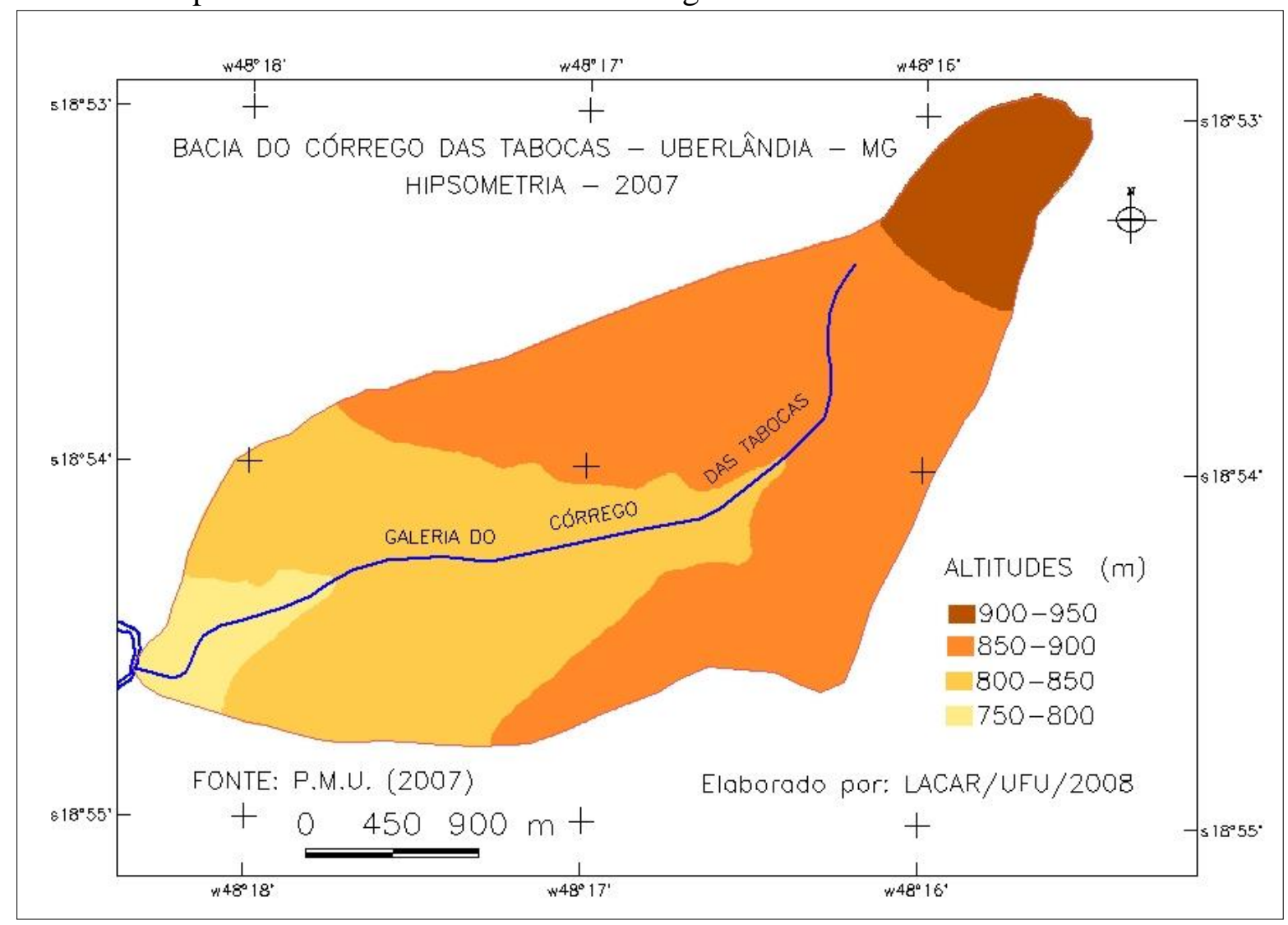

Fonte: Prefeitura Municipal de Uberlândia, 2008.

As formas de relevo que ocorrem em Uberlândia, segundo AB'SABER , 1971 (apud Baccaro, 1989, p. 17), pode ser denominado de Domínio dos Chapadões Tropicais do Brasil Central e para o RADAM, 1983 (apud Baccaro, 1989, p. 17) pode ser também denominado como Planaltos e chapadas da Bacia Sedimentar do Paraná inserida na subunidade Planalto Setentrional da Bacia Sedimentar do Paraná.

Segundo Baccaro (1989), o relevo de Uberlândia é predominantemente dissecado em formas tabulares amplas, apresentando escarpas com níveis superiores a 150 metros. A área de relevo dissecado é aquela que:

Correspondem ao setor com topos aplainados entre 700 e 900 metros, tendo no substrato, principalmente, a Formação Adamantina e uma cobertura Cenozóica. As vertentes são suaves, recobertas pelo cerrado e em muitos locais interrompidas por rupturas mantidas pela laterita, que são os locais preferenciais para afloramento do lençol subterrâneo, constituindo pequenas nascentes. (BACCARO, 1989, p.20)

OBSERVATORIUM: Revista Eletrônica de Geografia, v. 9, n. 3, p. 235-261. set./dez. 2018. 
Bacia do Córrego das Tabocas em Uberlândia - MG

Arlei Teodoro de Queiroz; Washington Luiz Assunção

Os aspectos físicos de Uberlândia podem ser caracterizados como:

Nas proximidades da área urbana, o relevo apresenta-se mais ondulado, com altitude que varia de 800 a $900 \mathrm{~m}$. Os rios e córregos correm sobre o basalto, apresentando várias cachoeiras e corredeiras, onde os solos são férteis, do tipo Latossolo Vermelho e Vermelho-Escuro. As declividades apresentam-se suaves, geralmente inferiores a $30 \%$. (PREFEITURA MUNICIPAL DE UBERLÂNDIA, 2007, p.22).

Mapa 4 - Declividade da Bacia do Córrego das Tabocas - Uberlândia-MG.

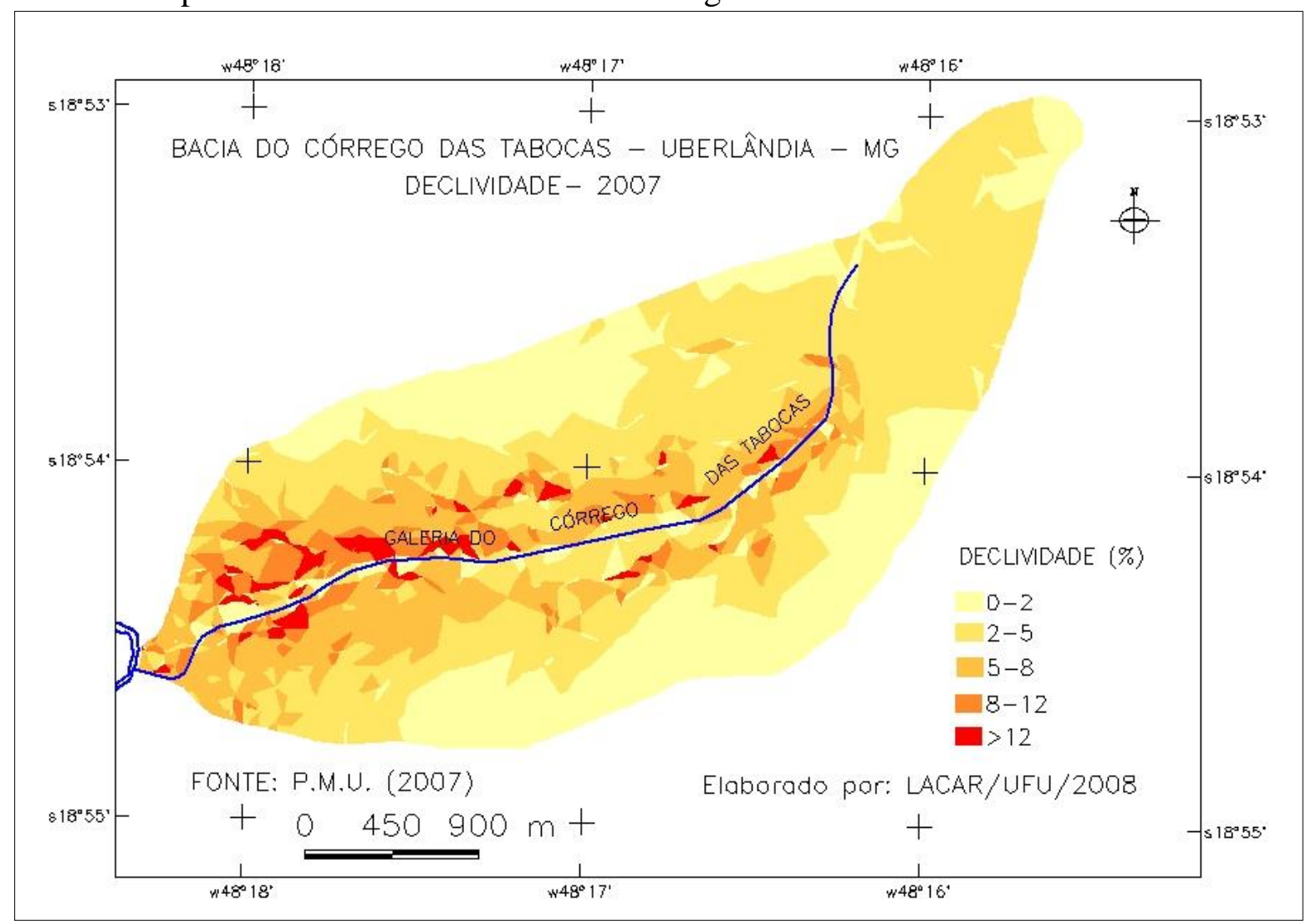

Fonte: Prefeitura Municipal de Uberlândia, 2008

Quanto à declividade na área da Bacia (Mapa 4), observa-se que está localizada em áreas de relevo plano a suave ondulado com o vale do córrego pouco encaixado, onde está construída a galeria do córrego das Tabocas. Essa maior declividade da Bacia próxima à galeria é um agravante para a ocorrência de enchentes no fundo do vale, pois aumenta a velocidade do escoamento superficial pluvial, provocando estragos na infraestrutura na área próxima à galeria.

O domínio morfoclimático predominante na área da Bacia é o Domínio Morfoclimático do Cerrado, sendo que o mesmo possui vegetação do tipo savana, e a maior parte de sua área está localizada no Planalto Central Brasileiro.

A geologia do município de Uberlândia pode ser classificada como:

[...] compreende a borda nordeste da Bacia Sedimentar do Paraná que, no local, é constituída de rochas sedimentares e magmatitos básicos de idade

OBSERVATORIUM: Revista Eletrônica de Geografia, v. 9, n. 3, p. 235-261. set./dez. 2018. 
O EVENTOS PLUVIOMÉTRICOS CONCENTRADOS NO ESPAÇO URBANO:

Bacia do Córrego das Tabocas em Uberlândia - MG

Arlei Teodoro de Queiroz; Washington Luiz Assunção

Mesozóica (Jurássico e Cretáceo), representadas pelas formações Botucatu, Serra Geral, Adamantina e Marília. Estas litologias encontram-se recobertas em grande extensão pelos sedimentos Cenozoicos da idade Terciária. A base deposicional é constituída de rochas do Grupo Araxá (Proterozóico) e do Complexo Basal Goiano (Arqueano). (NISHIYAMA, 1989, p.09)

Segundo Nishiyama (1989), na área urbana de Uberlândia, onde está localizada a Bacia do Córrego das Tabocas, há o afloramento do basalto da Formação Serra Geral tanto no vale do rio Uberabinha quanto de afluentes, e nota-se, também, a presença de sedimentos de idade Cenozoica, que recobre quase toda extensão do município.

\section{Clima local}

O clima de Uberlândia é caracterizado por duas estações, verão quente e chuvoso e inverno seco e com temperaturas amenas. Sobre o sistemas atmosféricos geradores de eventos pluviais concentrados na região, Mendes (2001) destaca a atuação:

(...) predominantemente pelos sistemas inter-tropicais e polares, que dão origem a alguns eventos pluviais mais concentrados, principalmente no verão, onde a atuação desses sistemas provoca, muitas vezes, danos sociais e econômicos através das chuvas, devido à precariedade ou mesmo à falta de adequação da infra-estrutura urbana, que não é capaz de suportar as precipitações concentradas. (MENDES, 2001, p.68)

De acordo com os dados climáticos da Estação Climatológica da Universidade Federal de Uberlândia, (Gráfico 1) nos meses mais frios, que são junho e julho, apresenta-se uma temperatura média inferior a $20^{\circ} \mathrm{C}$. No entanto, a temperatura média dos meses mais quentes é superior a $23^{\circ} \mathrm{C}$, ultrapassando os $24^{\circ} \mathrm{C}$ em outubro, sendo que a temperatura média anual em Uberlândia é $22,4^{\circ} \mathrm{C}$. Já em relação à média das precipitações nota-se que nos meses de outubro a abril ocorrem $92 \%$ do total de precipitação anual, enquanto que os outros $8 \%$ restantes ocorrem nos meses de maio à setembro, sendo que a média pluviométrica anual em Uberlândia é de 1583 mm. 
Gráfico 1 - Climograma de Uberlândia: MG (1981-2009).

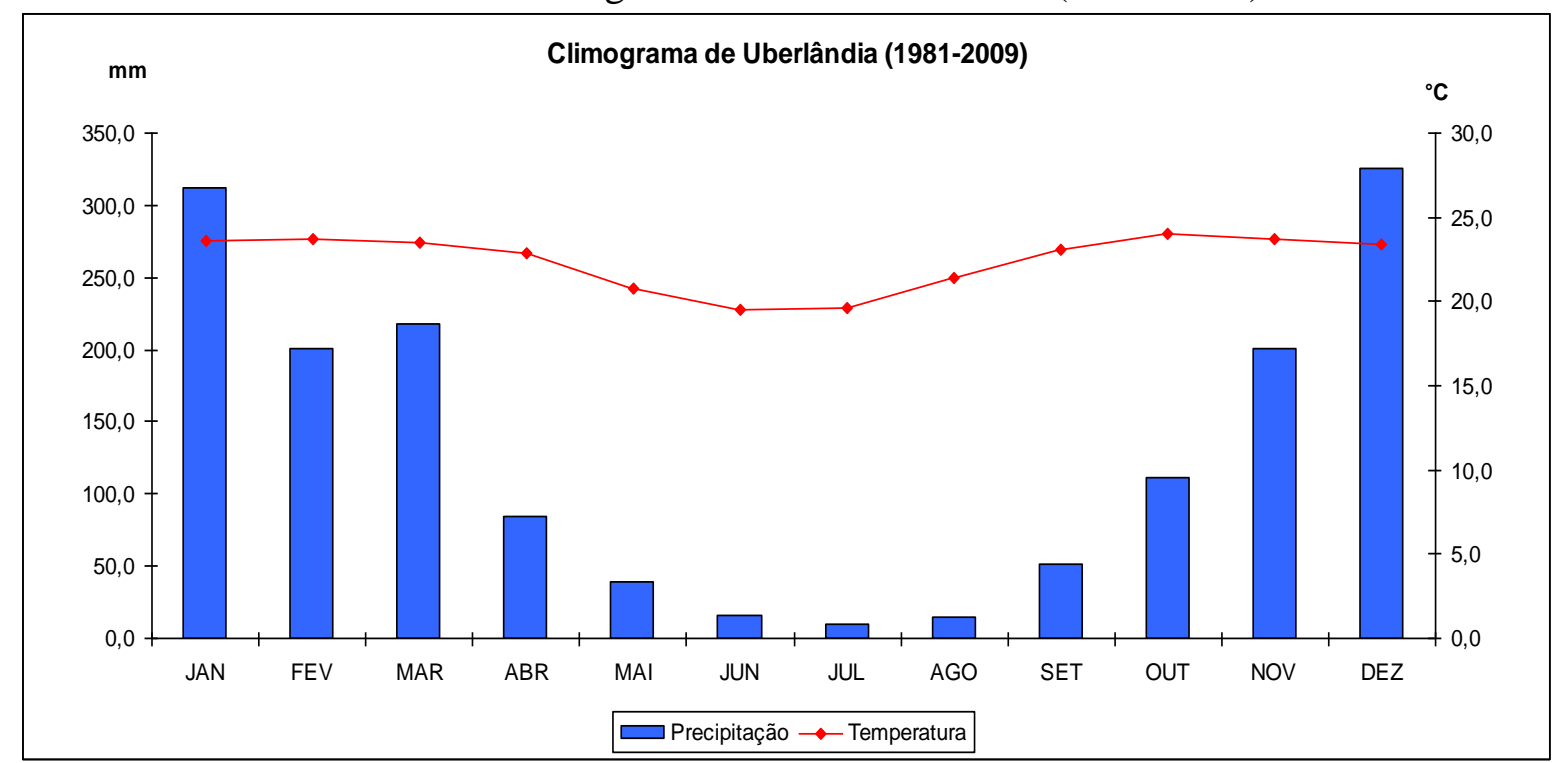

Fonte: Laboratório de Climatologia e Recursos Hídricos, Instituto de Geografia, Universidade Federal de Uberlândia.

Quanto ao clima de Uberlândia vale destacar a atuação das massas de ar como importante elemento na definição climática, sendo que ao longo do ano, verifica-se a atuação de quatro massas de ar: Massa Equatorial Atlântica (MEC), Massa Tropical Continental (MTC ou TC), Massa Tropical Atlântica (MTA) e Massa Polar Atlântica (MPA ou PA). Além das massas citadas, atuam também, a Frente Polar Atlântica (FPA), Instabilidade Tropical (IT) e Tropical Atlântica continentalizada (TAc).

Deste modo, segundo Mendes (2001) a sazonalidade existente entre os períodos chuvosos e quentes, frios e secos, durante o ano, se deve à alternância de atuação das massas tropicais e polares. No verão (período chuvoso) em Uberlândia:

(...) as condições de tempo sobre a cidade são controladas, principalmente, pelos sistemas produtores de instabilidade, como a FPA, IT e a TC, responsáveis pelas precipitações que ocorrem nesta época do ano. Por outro lado, também atuam sobre Uberlândia, nesse período do ano, os sistemas produtores de estabilidade, a PA e TAc, que causam a diminuição da cobertura do céu, da nebulosidade e da umidade relativa. (MENDES, 2001, p.90)

\section{Metodologia}


O EVENTOS PLUVIOMÉTRICOS CONCENTRADOS NO ESPAÇO URBANO:

Bacia do Córrego das Tabocas em Uberlândia - MG

Arlei Teodoro de Queiroz; Washington Luiz Assunção

Para melhor compreensão dos diversos problemas relacionados com a drenagem urbana, inundações e enchentes que ocorrem na Bacia do Córrego das Tabocas, foram utilizados dados de 11 pluviômetros localizados na Bacia e no seu entorno (Foto 1).

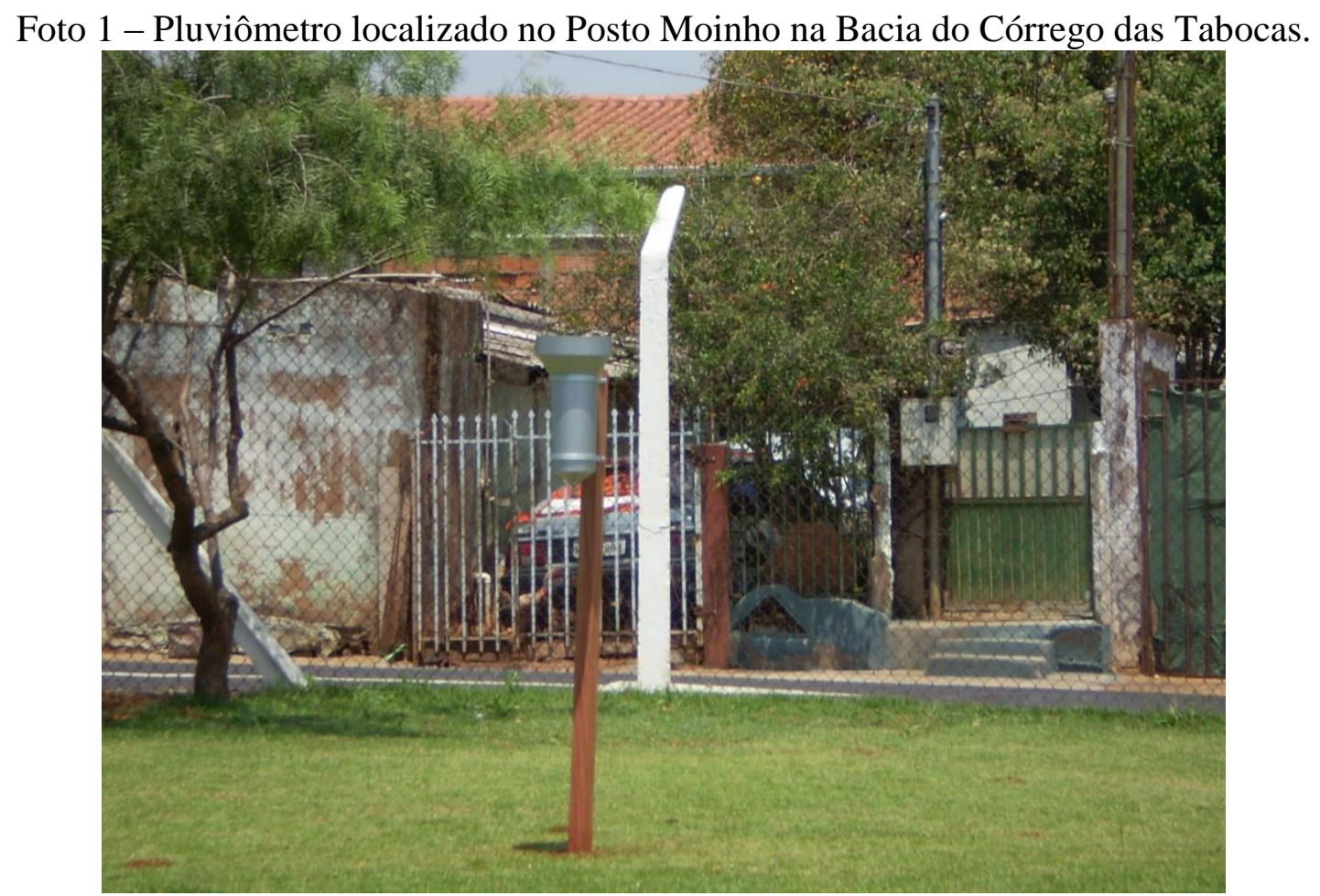

A partir dos dados coletados nos pluviômetros deu-se início a análise dos dois eventos pluviométricos concentrados que ocorreram nos dias 12 e 26 de novembro de 2007. Foram destacados esses dois eventos devido, principalmente, aos intensos estragos provocados na infraestrutura presente na Bacia.

Os eventos pluviométricos concentrados dos dias 12 e 26 de novembro de 2007 foram analisados utilizando três métodos. O primeiro foi através da análise das cartas sinóticas de superfície fornecidas pelo Instituto Nacional de Pesquisas Espaciais (INPE). O segundo foi analisando os índices pluviométricos registrados na Bacia e os dados climatológicos da Estação Climatológica Convencional e Automática da Universidade Federal de Uberlândia, relacionando estes dados com as cartas sinóticas. Sendo que a Estação Climatológica localizase a aproximadamente $2,5 \mathrm{~km}$ da Bacia.

O último método utilizado para analisar os dois eventos foi através da elaboração do mapa de isoietas (precipitação) dos dois eventos, sendo que os mapas foram confeccionados a partir da base cartográfica, contendo o limite da Bacia, a qual foi delimitada utilizando as 
O EVENTOS PLUVIOMÉTRICOS CONCENTRADOS NO ESPAÇO URBANO:

Bacia do Córrego das Tabocas em Uberlândia - MG

Arlei Teodoro de Queiroz; Washington Luiz Assunção

curvas de nível com equidistância vertical de 1 metro, do mapa topográfico da área urbana de Uberlândia, elaborado pela Prefeitura Municipal de Uberlândia. Utilizando esta base cartográfica juntamente com os dados dos pluviômetros localizados na Bacia, no Aeroporto de Uberlândia e na Estação Climatológica da Universidade Federal de Uberlândia, foi elaborado o mapa de isoietas a partir do software SPRING 4.4.3 (Sistema de Processamento de Informações Georreferenciadas), desenvolvido pelo INPE (Câmera et. al, 1996), sendo que os dados pluviométricos foram importados para o banco de dados do SPRING 4.3.3 (Sistema de Processamento de Informações Georreferenciadas) para geração das grades retangulares com valores e a espacialização dos índices pluviométricos para toda a Bacia, nos dois eventos. A partir das grades, foram então gerados dois mapas de classes de precipitação da Bacia para os dias 12 e 26 de novembro de 2007.

Além dos mapas de isoietas, foram confeccionados outros cinco (5) mapas a partir da base cartográfica: declividade, hipsometria, uso do solo, localização da Bacia e dos pluviômetros. Os mapas de declividade e hipsometria foram gerados a partir do limite da Bacia e das curvas de nível no SPRING, produzindo o modelo digital do terreno (MDT) e utilizando as funções de grade Triangular e Regular. Já o mapa de uso do solo urbano, contendo a delimitação das áreas permeáveis e impermeáveis, foi elaborado também no software SPRING 4.3, utilizando o método de interpretação visual em tela da fotografia aérea do município de Uberlândia, com resolução espacial compatível com a escala 1:2.000, fornecida pela Prefeitura Municipal de Uberlândia. O mapa de localização da Bacia foi elaborado utilizando o limite da Bacia e o mapa do perímetro urbano de Uberlândia.

Além do levantamento de dados primários referentes à precipitação e mapeamento, foi feito também, um levantamento de dados secundário, através de pesquisa bibliográfica em livros, jornais, dissertações, monografias e sites que tratam do tema abordado neste trabalho.

\section{Análise dos eventos pluviométricos concentrados nos dias 12 e 26 de novembro de 2007 na Bacia do Córrego das Tabocas}

Neste tópico serão analisados os eventos pluviométricos concentrados ocorridos na bacia nos dias 12 e 26 de novembro de 2007.

\section{Análise das cartas sinóticas do dia 12 de novembro de 2007}


As análises sinóticas destacam a atuação de duas frentes frias na região Sudeste do Brasil, próximo ao dia 12 de novembro de 2007, sendo que a primeira foi:

(...) uma onda frontal que se formou no RS no dia 09 cujo ramo frio afetou grande parte da Região Sul e a faixa leste da Região Sudeste. Esta frente fria chegou ao sul do RJ durante o dia 12 e avançou até o norte do Estado no dia 13. A formação do centro de baixa pressão desta onda frontal apresentou um desenvolvimento rápido, atingindo o valor mínimo de pressão de $961 \mathrm{hPa}$ no dia 10, porém, afastado do continente. A formação deste sistema provocou evento severo no Uruguai, onde foi registrado queda de granizo (Tacuarembó). Esta frente foi o segundo sistema do mês que causou queda significativa de temperatura na Região Sul, principalmente no RS e em SC. Em algumas localidades foram registrados valores mínimos de temperatura que oscilaram entre 3 e $6^{\circ} \mathrm{C}$. Em São Joaquim houve registro de geada fraca. Durante seu deslocamento pelo litoral paulista e fluminense este sistema provocou acumulados significativos em algumas cidades. Em Ubatuba choveu aproximadamente $94 \mathrm{~mm}$ em dois dias. Segundo dados da Georio$\mathrm{RJ}$, em alguns bairros da capital fluminense, foram registrados acumulados acima de $80 \mathrm{~mm}$ em 24 horas. (CPTEC, 2007)

Já a segunda frente fria:

(...) atingiu a Bahia Blanca no dia 13 às 12GMT. Este sistema deslocou-se pelo litoral do continente chegando até Vitória-ES no dia 16. Esta frente fria, até então, foi o mais intenso deste mês e sua passagem pelo Sul do Brasil provocou muitos temporais e acumulados significativos. Esta frente também trouxe chuva e baixas temperaturas para grande parte da Argentina, do Uruguai, da Região Sul (em algumas áreas houve registro de geada), de SP, do sul e sudeste de MG, no RJ e ES. (CPTEC, 2007)

No dia 12 de novembro de 2007, em Uberlândia, segundo o CPTEC, ocorreu uma chuva forte na cidade, cuja causa foi a divergência em altos níveis, calor e umidade elevados, sendo que esse evento produziu os seguintes impactos:

Chuva causa prejuízo de R $\$ 1,5$ milhão em Uberlândia. Em 30 minutos, choveu a quantidade esperada para o mês inteiro. Após a chuva do início desta semana, as prefeituras das cidades mineiras mais afetadas começaram a calcular os prejuízos. Em Uberlândia, a estimativa é que seja investido cerca de $R$ \$ 1,5 milhão apenas para limpeza e recuperação das áreas atingidas pelo temporal. $\mathrm{O}$ vento atingiu 75 quilômetros por hora. $\mathrm{O}$ asfalto de uma avenida que tinha sido recapeada há menos de duas semanas se soltou. Quase cem veículos e 46 árvores foram arrastados pela água. (G1 apud CPTEC, 2007).

Figura 1 - Cartas sinóticas de superfície do dia 12 e 13 de novembro de 2007. 

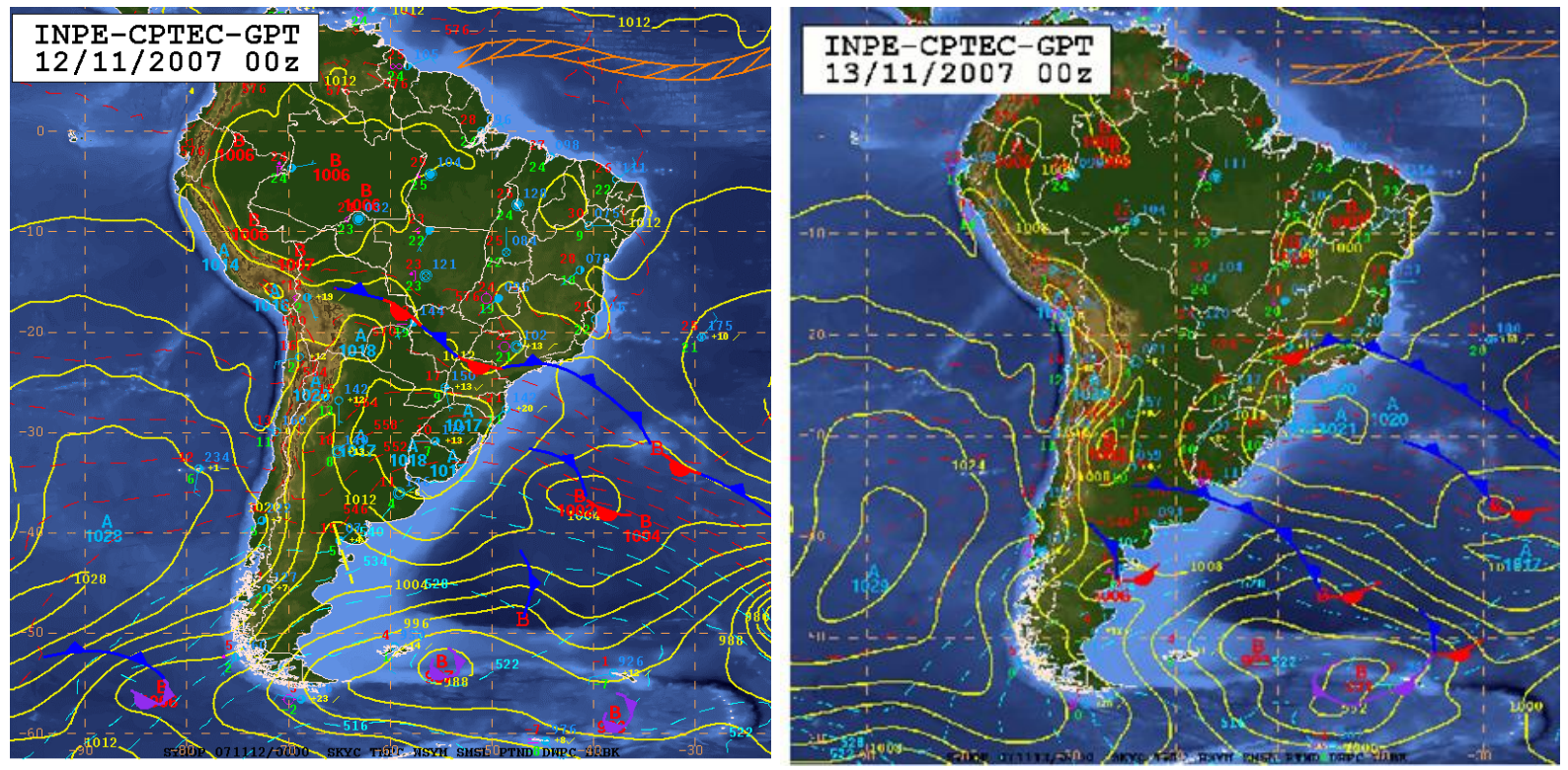

Fonte: CPTEC.

Uberlândia, neste dia, de acordo com os dados da Estação Climatológica Convencional da Universidade Federal de Uberlândia, apresentava uma cobertura do céu de $90 \%$ no período da manhã, $80 \%$ à tarde e $100 \%$ à noite, sendo que a noite com nuvens do tipo nimbus e cumulunimbus, que são nuvens características de chuva forte. Os ventos apresentavam velocidade de $1 \mathrm{~m} / \mathrm{s}$, com direção Nordeste, de manhã, calmaria a tarde e $3 \mathrm{~m} / \mathrm{s}$ a noite com direção Sul. A umidade relativa de manhã era 89\%, à tarde de $60 \%$ e à noite de 96\%. Já a pressão atmosférica reduzida a $0^{\circ} \mathrm{C}$ neste dia apresentava $916,7 \mathrm{mb}$ de manhã, 912,6 mb de tarde e 914,0 mb de noite. Associando esses dados com as cartas sinóticas de superfície (Figura 1) nota-se que Uberlândia estava sob atuação de dois sistemas produtores de instabilidade, sendo a Frente Polar Atlântica (FPA) ${ }^{1}$ e a Instabilidade Tropical (IT). Esta última provocada por uma ampla área de convergência de umidade associada a um transporte de umidade da região Amazônica, sendo que esses sistemas provocaram uma associação de temperatura e umidade do ar alta que provocou uma chuva moderada $(5,1$ a $20,0 \mathrm{~mm} / \mathrm{h}$ ou 6,0 $\mathrm{mm} / 10 \mathrm{~min}$ ) das $19 \mathrm{~h} 50 \mathrm{~min}$ às $21 \mathrm{~h} 40 \mathrm{~min}$ do dia 12 de novembro de 2007 , ou seja, com duração de 1h 50min, na Estação Climatológica da UFU no Campus Santa Mônica.

No Gráfico 2 pode-se observar algumas mudanças no registro de alguns elementos climáticos próximo ao horário em que ocorreu o evento pluviométrico, registradas na Estação Climatológica Automática da Universidade Federal de Uberlândia, sabendo que os horários registrados na Gráfico 2 são UTC, ou seja, 3 horas adiantados do fuso horário de Uberlândia. Nota-se que às 22 UTC (19 horas em Uberlândia) a temperatura registrada era de $25,5^{\circ} \mathrm{C}$, sendo que na hora seguinte, ou seja, às 23 UTC (20 horas), a temperatura teve uma queda de 
O EVENTOS PLUVIOMÉTRICOS CONCENTRADOS NO ESPAÇO URBANO:

Bacia do Córrego das Tabocas em Uberlândia - MG

Arlei Teodoro de Queiroz; Washington Luiz Assunção

$8,4^{\circ} \mathrm{C}$, atingindo $17,1^{\circ} \mathrm{C}$. Já a umidade relativa entre esses dois horários (22 e 23 UTC), apresentou amplitude de 34\%, registrando 59\% às 22 UTC e 93\% às 23 UTC. No intervalo entre 22 e 23 UTC foi registrado rajada de ventos de $20,6 \mathrm{~m} / \mathrm{s}$ ou 74,1 km/h, que, de acordo com a escala de Beaufort, é considerada com grau 8, designada como muito forte e seus efeitos pode ser a quebra de galhos de árvores e a difícil circulação de pessoas. Todas essas mudanças ocorridas foram resultado dos dois sistemas produtores de instabilidade citados acima, que culminou numa precipitação de $24,2 \mathrm{~mm}$ entre as 22 e 23 UTC e 12,2 $\mathrm{mm}$ das 23 às 00 UTC.

Gráfico 2 - Dados da Estação Automática de Uberlândia dos dias 12 e 13 novembro de 2007. 
O EVENTOS PLUVIOMÉTRICOS CONCENTRADOS NO ESPAÇO URBANO:

Bacia do Córrego das Tabocas em Uberlândia - MG

Arlei Teodoro de Queiroz; Washington Luiz Assunção

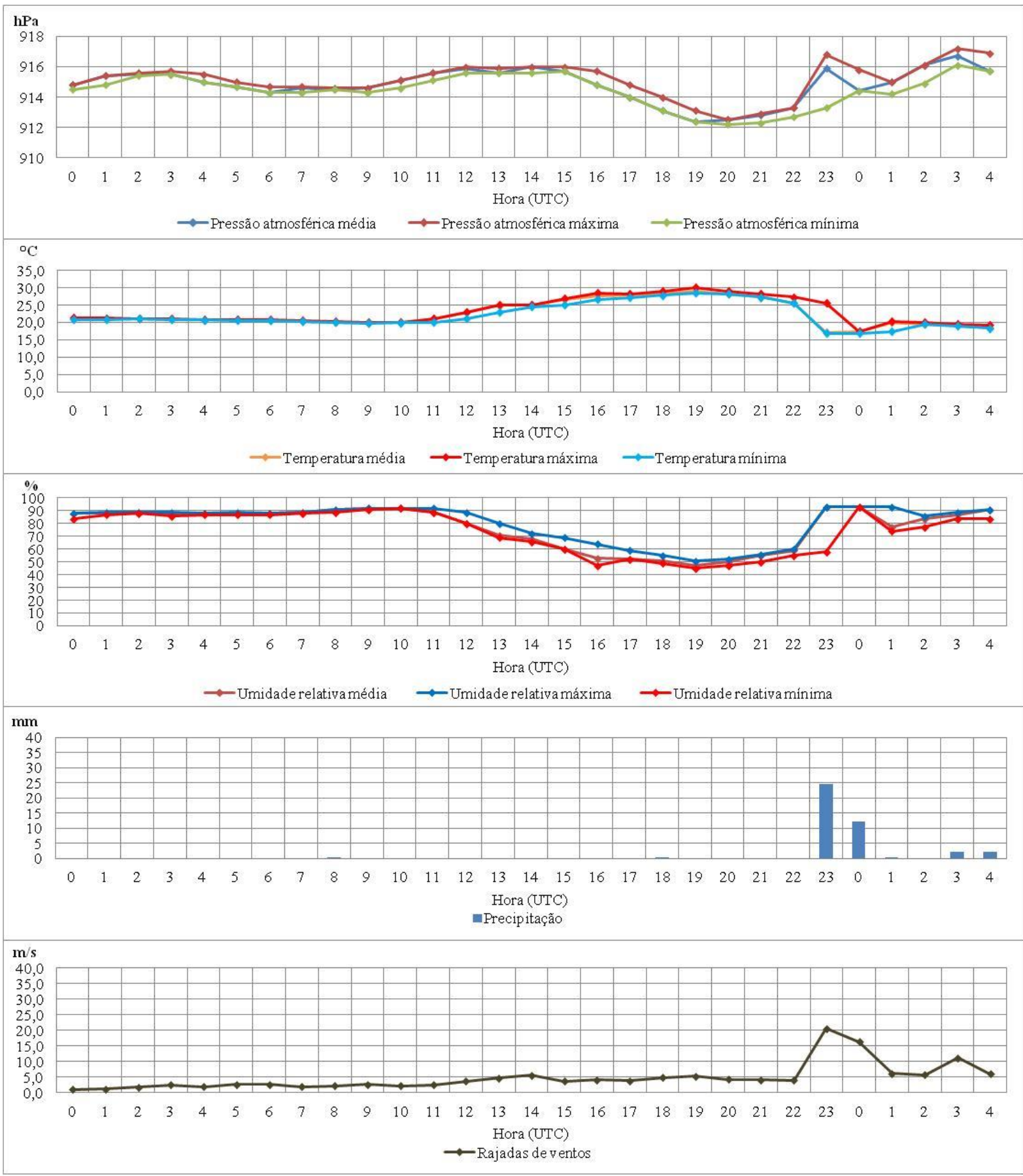

Fonte: INMET (Instituto Nacional de Meteorologia).

\section{Análise das cartas sinóticas do dia 26 de novembro de 2007}

Sobre o evento pluviométrico concentrado que ocorreu no dia 26 de novembro de 2007, vale destacar que, segundo as análises sinóticas, elaboradas pelo Centro de Previsão do Tempo e Estudos Climáticos (CPTEC), nos dias que antecederam e sucederam o evento, nas porções central, sul e leste da América do Sul houve a atuação de um sistema que provocou instabilidade nas condições meteorológicas, sendo que, conforme relatado pelo CPTEC:

OBSERVATORIUM: Revista Eletrônica de Geografia, v. 9, n. 3, p. 235-261. set./dez. 2018. 
(...) uma frente fria de fraca intensidade que apenas afetou a parte sul do litoral da província de Buenos Aires. Este sistema chegou até o RS entre os dias 23 e 24. No entanto, não foram registradas chuvas significativas e descargas elétricas. Este sistema se deslocou até SC, onde passou a ser um sistema estacionário no dia 25. A partir deste dia o deslocamento de um cavado na troposfera média favoreceu a formação de uma nova onda frontal com características subtropicais, cujo ramo frio avançou pela faixa litorânea chegando a capital paulista no dia 27 às $12 \mathrm{Z}$. O ar relativamente mais frio e seco pós-frontal provocou temperaturas mínimas baixas no Sul do país, principalmente, na Serra Gaúcha e Catarinense onde foram registradas ocorrências de geada na madrugada do dia 27 e do dia 29. Estes eventos anômalos somaram seis ocorrências de geada nestas localidades e superaram o antigo recorde de eventos de geada para o mês de novembro registradas no ano de 1999 (cinco ocorrências). Este sistema seguiu até o sul da BA e foi responsável por acumulados significativos nesta região. Entre os dias 27 e 28 este sistema deu origem a formação de uma nova Zona de Convergência do Atlântico Sul (ZCAS) (CPTEC, 2007).

Figura 2 - Carta sinótica de superfície do dia 26 de novembro de 2007.

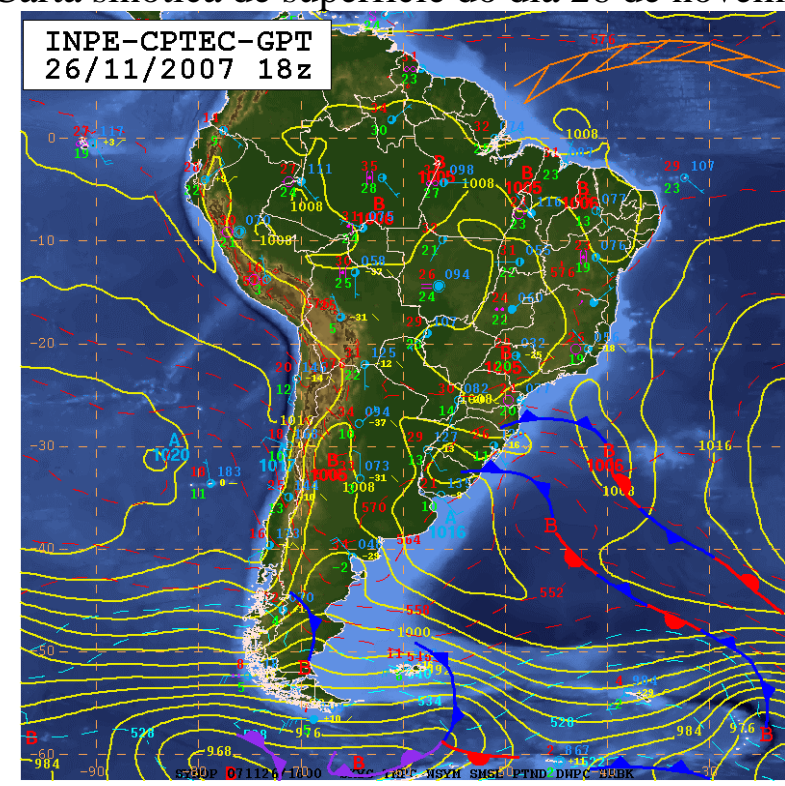

Fonte: CPTEC.

Uberlândia, neste dia, de acordo com os dados da Estação Climatológica Convencional da Universidade Federal de Uberlândia, apresentava uma cobertura do céu de $80 \%$ no período da manhã, $90 \%$ à tarde e $40 \%$ à noite, sendo que à tarde com nuvens do tipo cumulus, estratos e cumulunimbus, que são nuvens características de chuva forte. Os ventos apresentavam velocidade de $1 \mathrm{~m} / \mathrm{s}$, com direção Nordeste, de manhã, calmaria a tarde e a noite. A umidade relativa de manhã era $77 \%$, à tarde $66 \%$ e a noite $99 \%$. Já a pressão atmosférica reduzida a $0^{\circ} \mathrm{C}$ neste dia apresentava 915,6 mb de manhã, 910,3 mb a tarde e 911,6 mb a noite. Associando esses dados com as cartas sinóticas de superfície (Figura 2), nota-se que em Uberlândia, neste dia, se encontrava uma zona de baixa pressão atmosférica, 
O EVENTOS PLUVIOMÉTRICOS CONCENTRADOS NO ESPAÇO URBANO:

Bacia do Córrego das Tabocas em Uberlândia - MG

Arlei Teodoro de Queiroz; Washington Luiz Assunção

principalmente nos períodos da tarde e da noite, sendo que esse fenômeno favorece a convergência dos ventos em baixos níveis e contribui para a atividade convectiva. Associado a essa baixa pressão, estava ocorrendo temperatura e umidade do ar alta. Com a atuação de todos esses elementos, as condições atmosféricas estavam propícias para a ocorrência de chuva forte (>20,0 mm/h ou >6,0 mm/10 min), que ocorreu entre as $15 \mathrm{~h} 35 \mathrm{~min}$ e $16 \mathrm{~h} 40 \mathrm{~min}$ do dia 26 de novembro de 2007, ou seja, com duração de 1h 5 min, na Estação Climatológica da UFU no Campus Santa Mônica.

No Gráfico 3, nota-se as alterações registradas nas condições meteorológicas próximo ao horário em que ocorreu o evento pluviométrico, registradas na Estação Climatológica Automática da Universidade Federal de Uberlândia. Verifica-se que as 18 UTC (15 horas em Uberlândia) a temperatura registrada era $27,8^{\circ} \mathrm{C}$, sendo que até as 19 UTC (16 horas) a temperatura teve uma queda de $9,4^{\circ} \mathrm{C}$, atingindo $18,4^{\circ} \mathrm{C}$. Já a umidade relativa entre esses dois horários apresentou amplitude de 39\%, registrando 53\% às 18 UTC e $92 \%$ as 19 UTC. A velocidade e direção do vento também sofreram alteração, sendo que as 18 UTC a velocidade do vento era de $0,5 \mathrm{~m} / \mathrm{s}$ ou $1,8 \mathrm{~km} / \mathrm{h}$ e a direção era $49^{\circ}$ ou NE, enquanto que as 19 UTC a velocidade já era $9,6 \mathrm{~m} / \mathrm{s}$ ou $34,5 \mathrm{~km} / \mathrm{h}$ e a direção era $256^{\circ}$ ou $\mathrm{SW}$. No intervalo entre os dois horários (18 e 19 UTC) foi registrado rajada de $22,4 \mathrm{~m} / \mathrm{s}$ ou $80,6 \mathrm{~km} / \mathrm{h}$, que segundo a escala de Beaufort essa rajada é considerada com grau 9, designada como duro e seus efeitos pode ser danos em árvores e impossibilidade de andar contra o vento. Todas essas mudanças ocorridas associadas a zona de baixa pressão que se encontrava em Uberlândia, culminou numa precipitação de 27,0 mm entre as 18 e 19 UTC e 18,4 mm das 19 as 20 UTC.

OBSERVATORIUM: Revista Eletrônica de Geografia, v. 9, n. 3, p. 235-261. set./dez. 2018. 
O EVENTOS PLUVIOMÉTRICOS CONCENTRADOS NO ESPAÇO URBANO:

Bacia do Córrego das Tabocas em Uberlândia - MG

Arlei Teodoro de Queiroz; Washington Luiz Assunção

Gráfico 3 - Dados da Estação Automática de Uberlândia, no dia 26 novembro de 2007.

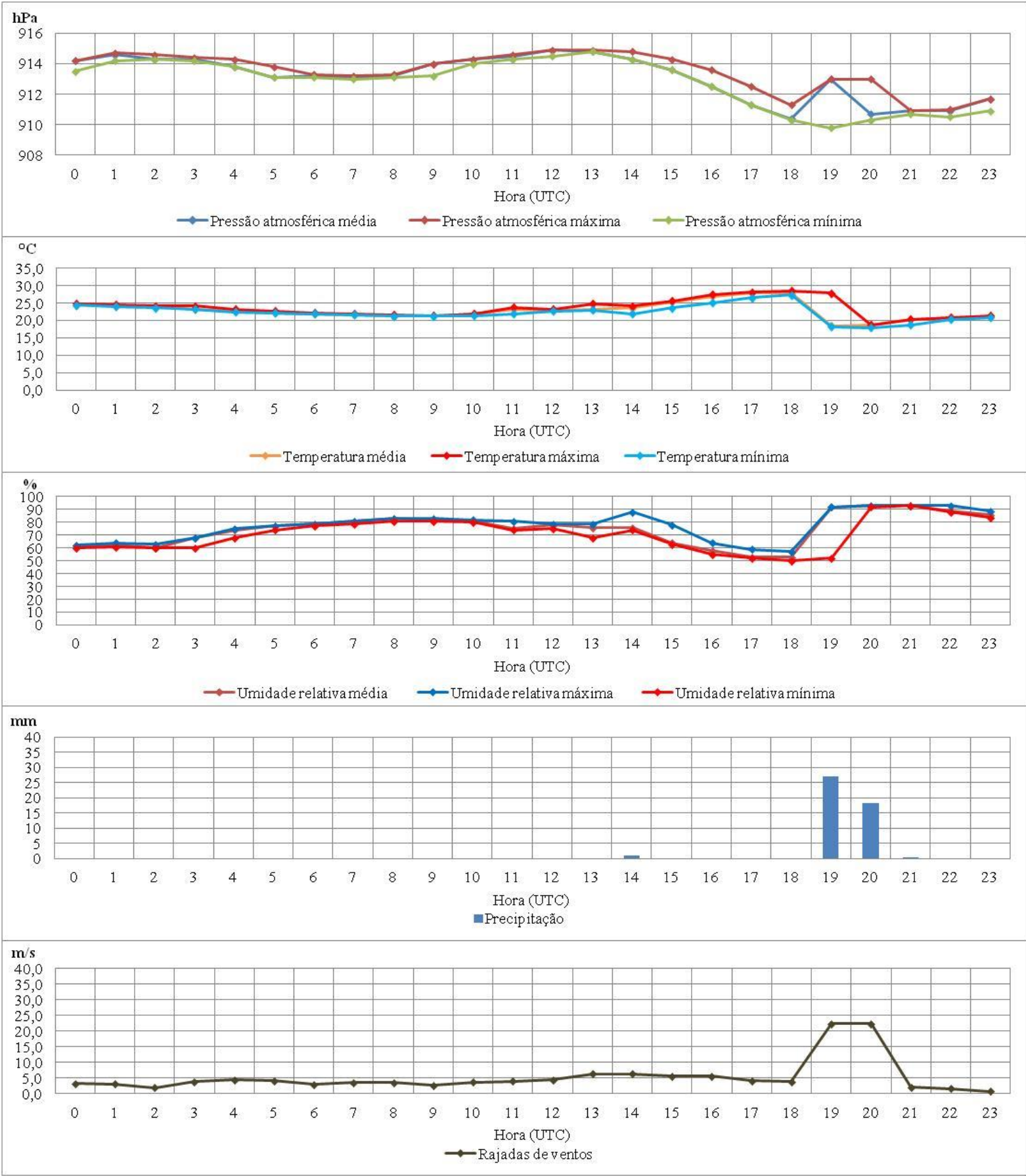

Fonte: INMET (Instituto Nacional de Meteorologia).

\section{Dinâmica dos eventos pluviométricos concentrados na Bacia}

A partir dos índices pluviométricos coletados em pluviômetros localizados na Bacia e no entorno, foram elaborados os mapas de isoietas dos dois eventos pluviométricos

OBSERVATORIUM: Revista Eletrônica de Geografia, v. 9, n. 3, p. 235-261. set./dez. 2018. 
O EVENTOS PLUVIOMÉTRICOS CONCENTRADOS NO ESPAÇO URBANO:

Bacia do Córrego das Tabocas em Uberlândia - MG

Arlei Teodoro de Queiroz; Washington Luiz Assunção

concentrados (12 e 26 de novembro de 2007), os quais serviram para a análise da dinâmica dos dois eventos.

No evento pluviométrico ocorrido no dia 12 de novembro de 2007, observa-se no Mapa 5 a espacialização dos índices pluviométricos, sendo que a partir do mapa nota-se que os maiores índices pluviométricos ocorreram à montante e na direção norte e nordeste da Bacia, onde os índices chegaram a variar de 74 a $81 \mathrm{~mm}$. Já as áreas com menor precipitação foram uma ao sul e outra a noroeste da Bacia, onde os índices variaram de 46 a $53 \mathrm{~mm}$.

Conforme mostra o Mapa 5, nota-se que além dos altos índices pluviométricos registrados nesse evento, outro agravante para a ocorrência de enchentes foi pelo fato das maiores alturas pluviométricas terem ocorridos a montante da bacia, pois sabe-se que o escoamento pluvial superficial nessa bacia segue para o fundo do vale, onde está localizada a Galeria Minervina Cândida (Córrego das Tabocas). Dessa forma, o volume precipitado a montante escoa em direção à galeria e ganha energia, o que associado ao que se precipitou na bacia em direção à jusante, acumula-se um volume elevado de água pluvial, nas avenidas localizadas próximo à galeria, provocando muitos estragos nessas avenidas devido ao grande volume do escoamento pluvial superficial concentrado.

Sabendo que a precipitação foi mais intensa à montante da Bacia, pode-se concluir que começou ocorrer precipitação na direção norte e noroeste da Bacia e foi perdendo intensidade de acordo que se deslocava para a jusante da Bacia. Essa precipitação foi responsável por diversos danos na infraestrutura na Avenida Minervina, principalmente nas áreas próximas à galeria fluvial, como pode ser observado na Foto 2. 
O EVENTOS PLUVIOMÉTRICOS CONCENTRADOS NO ESPAÇO URBANO:

Bacia do Córrego das Tabocas em Uberlândia - MG

Arlei Teodoro de Queiroz; Washington Luiz Assunção

Foto 2 - Estragos provocados pela enchente ocorrida no dia 12/11/2007 na Bacia do Córrego das Tabocas (Avenida Professora Minervina Cândida de Oliveira).

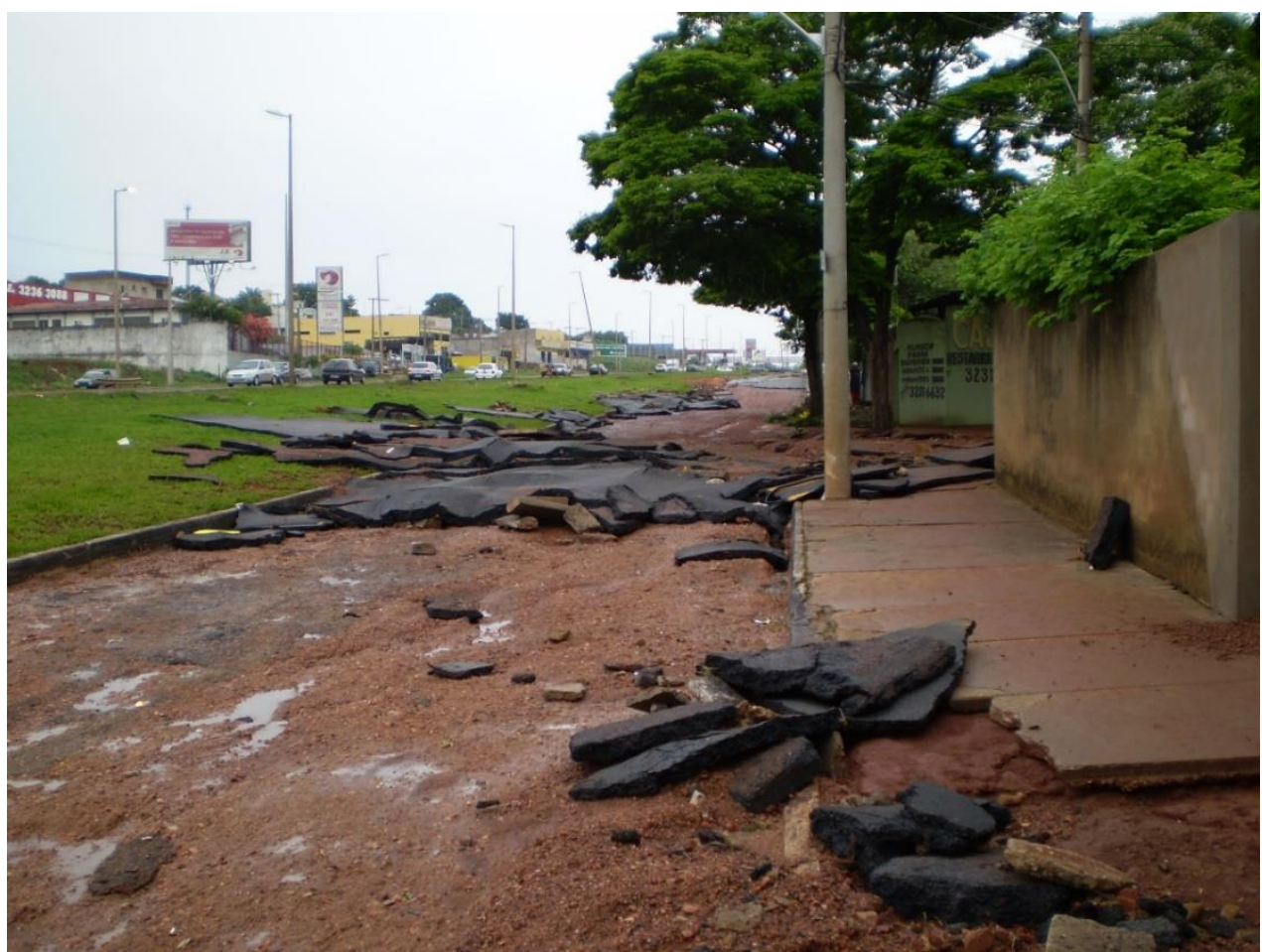

Mapa 5 - Precipitação (mm) ocorrida na Bacia do córrego das Tabocas dia 12/11/2007. 
O EVENTOS PLUVIOMÉTRICOS CONCENTRADOS NO ESPAÇO URBANO:

Bacia do Córrego das Tabocas em Uberlândia - MG

Arlei Teodoro de Queiroz; Washington Luiz Assunção

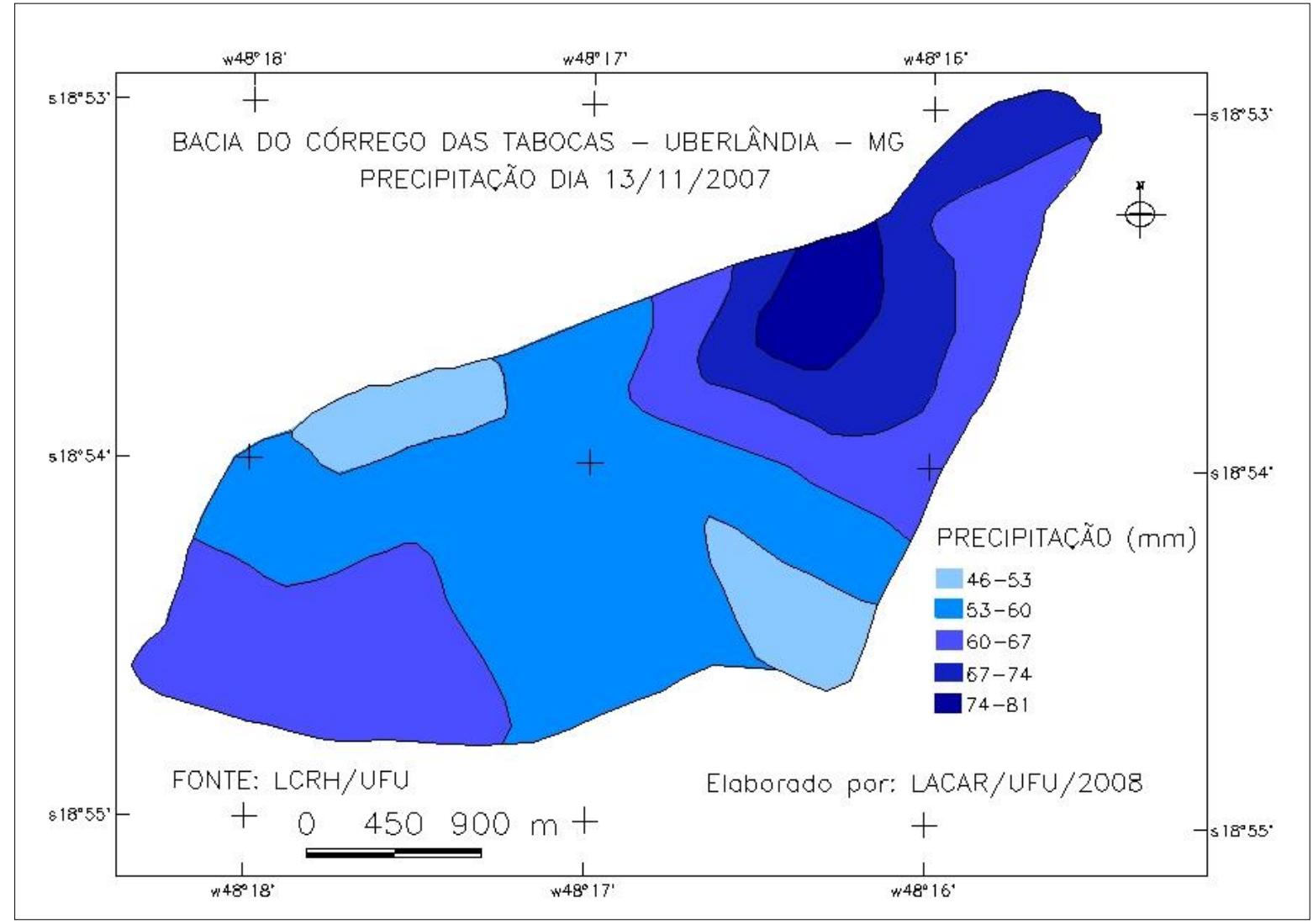

Fonte: LCRH/UFU, 2008.

O segundo evento pluviométrico concentrado analisado ocorreu no dia 26 de novembro de 2007. De acordo com o Mapa 6, pode-se notar que os maiores índices pluviométricos ocorreram à jusante da Bacia com precipitação entre 50 e $55 \mathrm{~mm}$. Já os menores índices pluviométricos ocorreram à montante e na direção norte da Bacia, variando de 35 a $40 \mathrm{~mm}$.

Quando se compara os eventos pluviométricos dos dias 12 e 26 de novembro de 2007, Mapas 5 e 6, observam-se que a dinâmica dos dois eventos ocorreram de forma diferente, pois enquanto no dia 12 os índices pluviométricos atingiram $81 \mathrm{~mm}$, no dia 26 o pico máximo atingido foi de $55 \mathrm{~mm}$. Portanto, a precipitação foi mais intensa no dia 12. Outro aspecto que merece destaque, quando se compara os dois eventos é quanto à área da Bacia onde ocorreram os maiores índices pluviométricos, já que no dia 12 os maiores valores atingiram os setores à montante da Bacia e no dia 26 foi à jusante, isto é, o contrário. Tal fato pode ser atribuído como um dos responsáveis pela maior ocorrência de danos provocados pela chuva no dia 12 , pois o volume precipitado a montante escoa em direção à Galeria da Minervina Cândida, percorrendo, assim, uma distância maior até a foz no Rio Uberabinha, além de ganhar energia nesse maior deslocamento em função da própria topografia do local. Deve-se destacar, ainda, a direção da chuva do dia 12 de novembro. Ela entrou pelo norte da Bacia e seguiu em direção

OBSERVATORIUM: Revista Eletrônica de Geografia, v. 9, n. 3, p. 235-261. set./dez. 2018. 
O EVENTOS PLUVIOMÉTRICOS CONCENTRADOS NO ESPAÇO URBANO:

Bacia do Córrego das Tabocas em Uberlândia - MG

Arlei Teodoro de Queiroz; Washington Luiz Assunção

à foz do córrego das Tabocas, isto é, à medida que a chuva seguia na direção sul, ela era acompanhada pelo escoamento pluvial superficial concentrado, que ganhava novo reforço com a precipitação que ocorria no momento.

Analisando o Mapa 6, pode-se concluir que no dia 26 a precipitação se deslocou da porção sul reduzindo a intensidade conforme se direcionava para a porção norte da bacia, com características de atividade convectiva, conforme já relatado. Sobre as precipitações convectivas na região, vale salientar que na maioria do casos ela ocorre em pontos isolados do região, podendo abranger apenas parte do espaço urbano de uma cidade, como é o caso de Uberlândia.

Mapa 6 - Precipitação (mm) ocorrida na Bacia do córrego das Tabocas dia 26/11/2007. 
O EVENTOS PLUVIOMÉTRICOS CONCENTRADOS NO ESPAÇO URBANO:

Bacia do Córrego das Tabocas em Uberlândia - MG

Arlei Teodoro de Queiroz; Washington Luiz Assunção

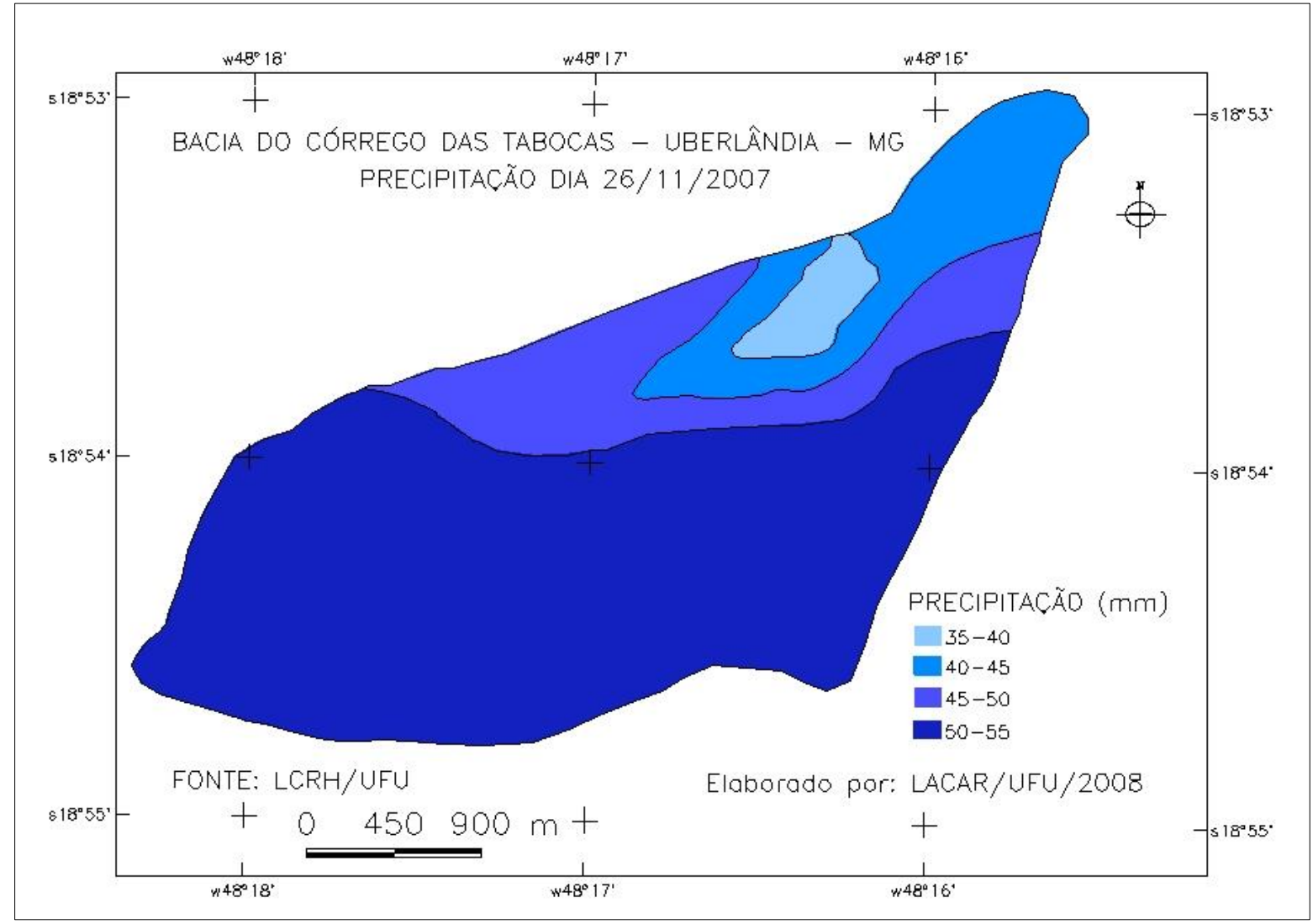

Fonte: LCRH/UFU, 2008.

$\mathrm{Na}$ Foto 3 pode-se observar os estragos provocados à infraestrutura na Bacia, principalmente próximo à galeria fluvial. 
O EVENTOS PLUVIOMÉTRICOS CONCENTRADOS NO ESPAÇO URBANO:

Bacia do Córrego das Tabocas em Uberlândia - MG

Arlei Teodoro de Queiroz; Washington Luiz Assunção

Foto 3 - Estragos provocados pela enchente ocorrida no dia 26/11/2007 na Bacia do Córrego das Tabocas (Rua Aldo de Souza).

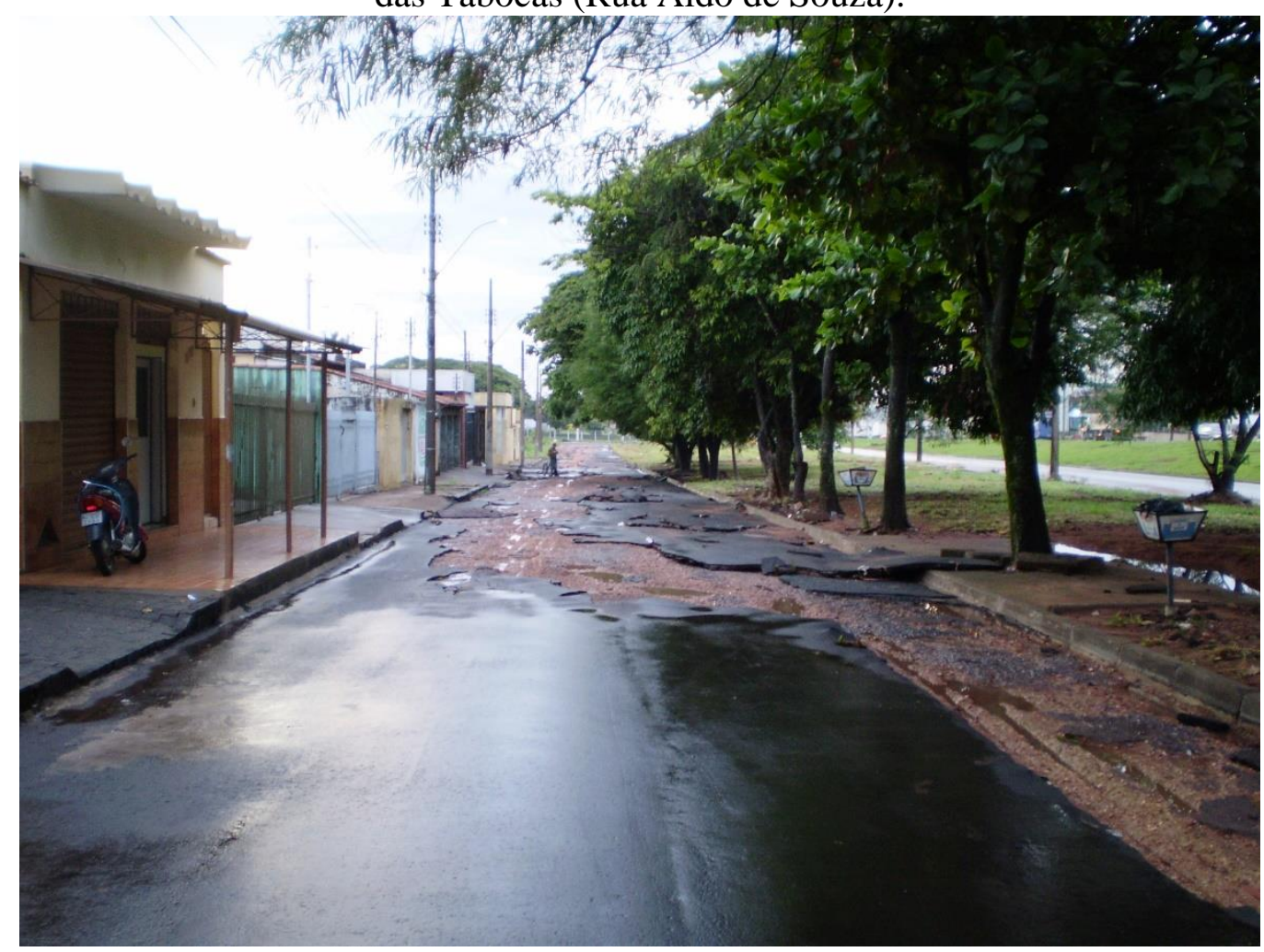

\section{Considerações finais}

Quanto ao problema das enchentes na Bacia do Córrego das Tabocas, pode-se concluir que são agravadas: pelo alto grau de impermeabilização dos solos na Bacia, chegando a 75,87\% de área impermeável que, além de não absorver parte das águas pluviais, contribui para o aumento na velocidade da água; pela alta declividade próxima à galeria onde se encontra o curso de água, aumentando a velocidade da água e, consequentemente, a destruição causada pelas águas pluviais; pela canalização e retificação do Córrego das Tabocas, o que aumenta a velocidade da água na galeria. Além disso, o alto grau de impermeabilização é decorrente de construções de concreto, asfalto dentre outros materiais no ambiente urbano. Estes produtos possuem característica de absorção da radiação, fato que associado a redução da área verde, provocando a elevação da temperatura nas cidades e, consequentemente, redução da pressão atmosférica, o que pode propiciar o aumento da ocorrência de eventos pluviométricos concentrados neste ambiente.

Outro fator importante observado foi quanto à eficiência dos bueiros que se localizam, principalmente, nas avenidas principais e nas partes baixas e médias da Bacia, sendo que a 
O EVENTOS PLUVIOMÉTRICOS CONCENTRADOS NO ESPAÇO URBANO:

Bacia do Córrego das Tabocas em Uberlândia - MG

Arlei Teodoro de Queiroz; Washington Luiz Assunção

área de captação das águas pluviais em que cada bueiro é responsável, muitas vezes é maior do que a capacidade do bueiro, sobrecarregando o mesmo e fazendo com que a água, na maioria das vezes, escoa superficialmente.

Os resíduos sólidos são outro fator agravante no que diz respeito ao problema das enchentes e inundações nas áreas urbanas, pois muitas vezes a deposição destes resíduos é realizada em locais impróprios provocando, através do transporte desses materiais, por meio de ventos e escoamento superficial, o entupimento das galerias pluviais, causando alagamento e aumentando o escoamento superficial nas ruas.

Nota-se também que, aparentemente, a Bacia, principalmente antes das obras iniciadas no final de 2007, possuía uma rede pluvial e fluvial ineficiente, pois não suportava todo o volume precipitado.

No que se refere à legislação municipal, nota-se que o uso do solo no Córrego das Tabocas não se respeita a Lei complementar $n^{\circ} 017$ de 04 de dezembro de 1991 - Meio Ambiente, Título II - Dos Recursos Hídricos, Capítulo I - Da prestação dos recursos hídricos, art. 77 e 78 que dizem:

Art. 77 - As nascentes ainda que intermitentes e nos chamados "Olhos d'água", qualquer que seja a situação topográfica, as faixas de proteção de vegetação nativa, deverão ter raio mínimo de cinqüenta metros.

Art. 78 - A faixa de proteção dos cursos d'água desde seu nível mais alto terá largura mínima:

I - de 30 (trinta) metros para os cursos d'água de menos de 10 (dez) metros de largura; (PREFEITURA MUNICIPAL DE UBERLÂNDIA, 2008)

A partir dos problemas levantados neste trabalho, vale destacar a importância dos estudos climáticos para o planejamento urbano. Nesse sentido, sugere-se para essa bacia que ocorra o incentivo à criação e ampliação das áreas verdes, tendo assim uma área permeável maior, retendo parte das águas pluviais nessas áreas; a criação, por parte do município, de um Plano de Drenagem Urbana e replanejamento do sistema de drenagem pluvial na bacia.

\section{Notas}

1 "uma onda frontal que se formou no RS no dia 09 cujo ramo frio afetou grande parte da Região Sul e a faixa leste da Região Sudeste. Esta frente fria". Tendo em vista as características do sistema frontal é possível afirmar que a mesma pode ser classificada FPA. Além disso, conforme destacado no subtítulo "Clima local" um dos sistemas produtores de instabilidade da região é a FPA.

\section{Referências}

OBSERVATORIUM: Revista Eletrônica de Geografia, v. 9, n. 3, p. 235-261. set./dez. 2018. 
Bacia do Córrego das Tabocas em Uberlândia - MG

Arlei Teodoro de Queiroz; Washington Luiz Assunção

AYOADE, J. O. Introdução à climatologia para os trópicos. Tradução Maria Juraci Zani dos Santos. Rio de Janeiro: Bertrand Brasil, 2002. 332 p.

BACCARO, C. A. D. Estudos geomorfológicos do município de Uberlândia. Sociedade e natureza, Uberlândia, v. 1, n. 1, p. 17-21, 1989.

BRASIL. Estatuto da Cidade. Estatuto da cidade: guia para implementação pelos municípios e cidadãos: Lei n. 10.257, de 10 de julho de 2001, que estabelece diretrizes gerais da política urbana. 2. Ed. Brasília: Câmara dos Deputados, Coordenação de Publicações, 2001. 273 p.

BRASIL. Ministério das Cidades. Plano diretor e saneamento ambiental. In: Plano

Diretor Participativo: Guia para a elaboração pelos municípios e cidadãos. Brasília, DF, 2004. 160 p. Disponível em: www.cidades.gov.br. Acesso em: 14 set. 2007.

BRASIL. Ministério do Meio Ambiente. SANTOS, R. F. (Org.). Vulnerabilidade ambiental: Desastres naturais ou fenômenos induzidos? Brasília: MMA, 2007. 192 p.

BRITO, J. L. S.; QUEIROZ, A. T.; ASSUNÇÃO, W. L. Eventos pluviais concentrados e a drenagem urbana: Bacia do Córrego Tabocas em Uberlândia - MG. In: SIMPÓSIO BRASILEIRO DE CLIMATOLOGIA GEOGRÁFICA, 8., 2008, Alto Caparaó. Anais... Uberlândia: Universidade Federal de Uberlândia, Instituto de Geografia, 2008. p. 366-377.

CENTRO DE PREVISÃO DO TEMPO E ESTUDOS CLIMÁTICOS (CPTEC/INPE). Disponível em: www.cptec.inpe.br. Acessado em: 09 abr. 2009.

CONTI, J. B. Clima e meio ambiente. São Paulo: Atual, 1998. 88 p.

FELTRAN FILHO, A. Contribuição à análise fluviométrica da Bacia do Rio Piracicaba. 1982. 188 f. Dissertação (Mestrado em Geografia) - Instituto de Geociências e Ciências Exatas, Universidade Estadual Paulista “Júlio de Mesquita Filho”, Rio Claro, 1982.

MENDES, P. C. Gênese e estrutura espacial das chuvas na cidade de Uberlândia - MG. 2001. 258 f. Dissertação (Mestrado em Geografia) - Programa de Pós-Graduação em Geografia, Universidade Federal de Uberlândia, Uberlândia, 2001.

MENDONÇA, F. O estudo do clima urbano no Brasil: Evolução, tendências e alguns desafios. In: MENDONÇA, F.; MONTEIRO, C. A. F. (Org.). Clima urbano. São Paulo: Contexto, 2003. p.175-192.

NISHIYAMA, L. Geologia do município de Uberlândia e áreas adjacentes. Sociedade e natureza, Uberlândia, v. 1, n. 1, p. 09-16, 1989.

PREFEITURA MUNICIPAL DE UBERLÂNDIA. Disponível em: www.uberlandia.mg.gov.br. Acessado em: 10 abr. 2010.

ROSA, R.; LIMA, S. C.; ASSUNÇÃO, W. L. Abordagem preliminar das condições climáticas de Uberlândia (MG). Sociedade e natureza, Uberlândia, v. 3, n. 5 e 6, p. 91-108, 1991. 
O EVENTOS PLUVIOMÉTRICOS CONCENTRADOS NO ESPAÇO URBANO:

Bacia do Córrego das Tabocas em Uberlândia - MG

Arlei Teodoro de Queiroz; Washington Luiz Assunção

SANTOS, M. A urbanização brasileira. 2. Ed. São Paulo: HUCITEC, 1994.

SILVA, E. M. O clima em Uberlândia - MG. 2003. 89 f. Monografia (Bacharelado) Instituto de Geografia, Universidade Federal de Uberlândia, Uberlândia, 2003.

SOARES, B. R. Habitação e produção do espaço em Uberlândia. 1988. 236 f. Dissertação (Mestrado em Geografia) - Faculdade de Filosofia, Letras e Ciências Humanas, Universidade de São Paulo, São Paulo, 1988.

TUCCI, C. E. M.; BRAGA, B. Clima e recursos hídricos. In: TUCCI, C. E. M.; BRAGA, B. (Org.). Clima e recursos hídricos no Brasil. Porto Alegre: ABRH, 2003. p. 01-30.

TUCCI, C. E. M.; COLLISCHONN, W. Drenagem urbana e controle de erosão. In: TUCCI, C. E. M.; MARQUES, D. M. L. M. (Org.). Avaliação e controle da drenagem urbana. Porto alegre: Ed. Universidade/UFRGS, 2000. p. 119-127.

TUCCI, C. E. M.; HESPANHOL, I.; CORDEIRO NETTO, O. M. A gestão da água no brasil: Uma primeira avaliação da situação atual e das perspectivas para 2025. Brasília, Agência Nacional de Águas, 2000. Disponível em:

http://www.unb.br/ft/enc/recursoshidricos/relatorio.pdf. Acessado em: 22 abr.2008. 